\title{
Piotr Podsiadlo*
}

\author{
DEFINICJA PRZEDSIĘBIORSTWA \\ JAKO BENEFICJENTA POMOCY PUBLICZNEJ \\ UDZIELANEJ NA USŁUGI UŻYTECZNOŚCI PUBLICZNEJ \\ REALIZOWANE PRZEZ JST ${ }^{* *}$
}

\begin{abstract}
Streszczenie
Pojęcie usługi świadczonej w ogólnym interesie gospodarczym jest pojęciem, którego znaczenie ewoluuje i zależy między innymi od potrzeb obywateli, zmian technologicznych i zmian na rynku, a także od preferencji społecznych i politycznych w państwie członkowskim. Z art. 106 ust. 2 Traktatu o funkcjonowaniu Unii Europejskiej wynika, że przedsiębiorstwa, którym powierzono wykonywanie UOIG to przedsiębiorstwa, którym powierzono „szczególne zadanie”. Zasadniczo powierzenie „określonego zadania z zakresu usług publicznych" oznacza świadczenie usług, których dane przedsiębiorstwo, ze względu na swój własny interes gospodarczy, nie podjęłoby się lub nie podjęłoby się w tym samym zakresie lub na tych samych warunkach. Zgodnie z art. 107 ust. 1 Traktatu reguły pomocy państwa zasadniczo mają zastosowanie jedynie wtedy, gdy beneficjent jest „przedsiębiorstwem”. Dlatego do celów stosowania reguł pomocy państwa kluczową kwestią jest ustalenie, czy dany podmiot świadczący usługę użyteczności publicznej należy uznać za przedsiębiorstwo.
\end{abstract}

Slowa kluczowe: pomoc publiczna, Unia Europejska, samorząd terytorialny, przedsiębiorstwo, usługi użyteczności publicznej

* Piotr Podsiadło, dr, Uniwersytet Ekonomiczny w Krakowie, Wydział Finansów, e-mail: podsiadp@uek.krakow.pl.

** Publikacja została sfinansowana ze środków przyznanych Wydziałowi Finansów Uniwersytetu Ekonomicznego w Krakowie w ramach dotacji na utrzymanie potencjału badawczego. 


\section{Wprowadzenie}

Podmiotami samorządu terytorialnego odpowiedzialnymi formalnie i politycznie za wykonywanie budżetów jednostek samorządu terytorialnego (JST) są organy wykonawcze. Faktyczna realizacja zadań polega jednak na ponoszeniu wydatków przez jednostki organizacyjne gmin, powiatów i województw samorządowych. Ze względu na specyfikę zadań realizowanych przez samorząd terytorialny organizacyjno-finansowe formy funkcjonowania tych jednostek w większości przypadków różnią się od tych, które działają w sektorze prywatnym. Są to bowiem podmioty, których działalność jest ograniczana ustawą o finansach publicznych ${ }^{1}$, co zmniejsza ich samodzielność finansową i ogranicza elastyczność gospodarowania środkami pieniężnymi. Forma organizacyjna podmiotu świadczącego usługi publiczne wyznacza ramy samodzielności finansowej zarówno władzom JST, jak również podmiotom, które tworzą i dostarczają te usługi. Działalność JST może być prowadzona w formach: jednostki budżetowej, samorządowego zakładu budżetowego, instytucji kultury, samodzielnego publicznego zakładu opieki zdrowotnej oraz spółki prawa handlowego. Spółki kapitałowe są obecnie powszechną formą wykonywania zadań o charakterze użyteczności publicznej z zakresu gospodarki komunalnej. Dotyczy to zaopatrzenia mieszkańców w wodę, oczyszczania ścieków i utrzymania czystości, a także transportu lokalnego. O wyborze sposobu i formy prowadzenia działalności komunalnej decyduje organ stanowiący JST. Dlatego też samorząd terytorialny może zlecać realizację usług podmiotom prywatnym oraz organizacjom pożytku publicznego, a niektóre zadania lokalne realizowane będą również w formie spółek prawa handlowego ze $100 \%$ udziałem JST, poprzez partnerstwo publiczno-prywatne, czy też kontraktowane u prywatnych podmiotów ${ }^{2}$.

Przedstawione powyżej organizacyjno-instytucjonalne ramy realizacji przez samorząd terytorialny zadań o charakterze użyteczności publicznej nawiązują do funkcjonującej na gruncie europejskiego prawa konkurencji zasady, że instytucje publiczne państw członkowskich UE mogą przyznawać szczególne uprawnienia, w szczególności uprawnienia monopolistyczne, przedsiębiorstwom z późn. zm.

${ }^{1}$ Ustawa z dnia 27 sierpnia 2009 r. o finansach publicznych, DzU z 2009 r. nr 157, poz. 1240

2 Specyficznym rodzajem spółek funkcjonujących w sferze użyteczności publicznej są jednoosobowe spółki gmin, powiatów i województw. W spółce takiej jednostkę samorządu terytorialnego reprezentuje organ wykonawczy. Natomiast w skład rady nadzorczej wchodzą przedstawiciele gminy, powiatu lub województwa powołani przez zarząd oraz członkowie wybierani przez pracowników spółki. 
publicznym lub prywatnym, świadczącym usługi w ogólnym interesie gospodarczym (UOIG). Pojęcie usługi świadczonej w ogólnym interesie gospodarczym w rozumieniu art. 106 Traktatu o funkcjonowaniu Unii Europejskiej (TFUE) ${ }^{3}$ oznacza, że zainteresowanemu przedsiębiorstwu zostało powierzone przez państwo szczególne zadanie, gdzie władze publiczne pozostają odpowiedzialne za określenie kryteriów i zasad świadczenia usług, niezależnie od statusu prawnego świadczącego je przedsiębiorstwa oraz od tego, czy usługa jest świadczona na zasadzie wolnej konkurencji. Powierzenie świadczenia usługi publicznej jest niezbędne w celu zdefiniowania obowiązków zainteresowanego przedsiębiorstwa oraz władz centralnych, regionalnych i lokalnych.

Mając na uwadze, że rekompensata przyznawana przedsiębiorcy przez władze publiczne za wykonywanie obowiązków w interesie publicznym stanowi pomoc publiczną $\mathrm{w}$ rozumieniu regulacji zawartych w Traktacie, istotna jest odpowiedź na pytanie, w jakich przypadkach zasady Traktatu dotyczące pomocy państwa odnoszą się do organizacji i finansowania UOIG.

Art. 107 ust. 1 TFUE stanowi, że: „Z zastrzeżeniem innych postanowień przewidzianych $\mathrm{w}$ Traktatach, wszelka pomoc przyznawana przez państwo członkowskie lub przy użyciu zasobów państwowych w jakiejkolwiek formie, która zakłóca lub grozi zakłóceniem konkurencji poprzez sprzyjanie niektórym przedsiębiorstwom lub produkcji niektórych towarów, jest niezgodna z rynkiem wewnętrznym w zakresie, w jakim wpływa na wymianę handlową między Państwami Członkowskimi”. Brak wyraźnie sformułowanego w art. 107 ust. 1 TFUE normatywnego zakazu udzielania pomocy publicznej daje państwom członkowskim możliwość sprawowania kontroli nad stosowaniem reguł pomocy niedozwolonej i dozwolonej. Zachowanie tej kontroli zostało potwierdzone szerokim zakresem dopuszczalności pomocy państwa jako zgodnej lub możliwej do uznania za zgodną z rynkiem wewnętrznym na podstawie art. 107 ust. 2 i 3 TFUE, w tym daleko idącymi uprawnieniami Komisji Europejskiej o charakterze uznaniowym i istotnymi kompetencjami legislacyjnymi Rady, które zostały ustanowione w art. 108 i 109 TFUE. Aby reguły pomocy publicznej ustanowione w art. 107-109 TFUE mogły znaleźć zastosowanie, beneficjentem pomocy musi być oczywiście przedsiębiorstwo ${ }^{4}$. Dlatego do celów stosowania reguł pomocy państwa kluczową kwestią jest ustalenie, czy dany podmiot świadczący

3 Traktat o Unii Europejskiej i Traktat o funkcjonowaniu Unii Europejskiej, wersje skonsolidowane - Dz. Urz. UE, C 83 z 30.03.2010.

${ }^{4}$ K. Bacon, The definition of State aid, w: European Community Law of State Aid, red. K. Bacon, Oxford University Press, Oxford - New York 2009, s. 35-41. 
usługi w interesie ogólnym należy uznać za przedsiębiorstwo. Celem artykułu jest analiza źródeł prawa oraz najważniejszych zasad stanowiących wykładnię dla pojęcia przedsiębiorstwa w odniesieniu do udzielania pomocy publicznej na usługi użyteczności publicznej realizowane przez jednostki samorządu terytorialnego.

\section{Ogólna wykładnia pojęcia przedsiębiorstwa w unijnym prawie konkurencji}

Za przedsiębiorstwo $\mathrm{w}$ sensie ekonomicznym uznaje się podmiot prowadzący działalność gospodarczą, która motywowana jest chęcią uzyskania korzyści majątkowych i ma na celu zaspokojenie potrzeb innych podmiotów życia społecznego przez wytwarzanie produktów lub świadczenie usług, przy czym działalność ta prowadzona jest samodzielnie na ryzyko właściciela ${ }^{5}$. Natomiast w ujęciu porządków prawnych państw członkowskich, a także w ujęciu różnych gałęzi prawa $\mathrm{w}$ ramach tego samego porządku prawnego, przedsiębiorstwo jest interpretowane w szerszym lub węższym zakresie w porównaniu do ujęcia stricte ekonomicznego. Z punktu widzenia unijnych reguł konkurencji pojęcie przedsiębiorstwa w ogóle nie ma jak dotychczas ustalonego jednolitego znaczenia ${ }^{6}$. Można powiedzieć, że: „W Traktacie o funkcjonowaniu Unii Europejskiej pojęcie przedsiębiorstwa występuje wielokrotnie, w poszczególnych przepisach tego Traktatu różni się w pewnym zakresie w zależności od kontekstu, w jakim jest użyte, ale w Traktacie brakuje definicji przedsiębiorstwa"7. Powoduje to, że pojęcie „przedsiębiorstwo” charakteryzuje się otwartą tekstowością, a znaczenie tego pojęcia określane jest w drodze orzecznictwa sądów unijnych. Stąd też w ujęciu prawa konkurencji Unii Europejskiej - na gruncie orzecznictwa sądów unijnych - ,przedsiębiorstwo” jest pojęciem autonomicznym i rozumiane jest jako „każda jednostka prowadząca działalność gospodarczą, niezależnie od jej statusu

5 S. Sudoł, Przedsiębiorstwo. Podstawy nauki o przedsiębiorstwie. Teorie i praktyka zarzadzania, Dom Organizatora TNOiK, Toruń 2002, s. 43.

6 J.L. Buendia Sierra, Exclusive Rights and State Monopolies under EC Law: Article 86 (former Article 90) of the EC Treaty, Oxford University Press, Oxford - New York 2000, s. 30.

7 K. Van de Castelle, M. Hocine, ,Favouring certain undertakings or the production of certain goods": Selectivity, w: EU Competition Law, vol. IV: State Aid, ed. W. Mederer, N. Pesaresi, M. Van Hoof, Claeys \& Casteels Publishing BV, Lueven 2008, s. 247. 
prawnego i sposobu finansowania"», przy czym działalnością gospodarczą jest „oferowanie towarów lub usług na danym rynku"9.

Podkreślić jednakże należy, że dla określenia przedsiębiorstwa w rozumieniu art. 107 TFUE jako ,,jednostki gospodarczej” nie jest o tyle istotne jego działanie na „danym rynku”, ile to, że jest ono beneficjentem pomocy ${ }^{10}$, który musi mieć zdolność prawną zarówno do przyjęcia korzyści z tytułu udzielonej pomocy, jak i zdolność do ponoszenia odpowiedzialności prawnej - np. ewentualny zwrot pomocy w przypadkach naruszenia reguł traktatowych. Oznacza to, że przedsiębiorstwo w rozumieniu art. 107 TFUE nie może nie mieć żadnego statusu prawnego ${ }^{11}$. Innymi słowy, przedsiębiorstwem w rozumieniu unijnego prawa konkurencji mogą być różnego rodzaju podmioty prowadzące działalność gospodarczą, niezależnie od ich prawnej formy organizacji oraz od tego, czy podlegają pod reżim prawa prywatnego, czy publicznego ${ }^{12}$. W rozumieniu przepisów prawa konkurencji Unii Europejskiej w sytuacji, gdy istnieje rynek danego towaru lub usługi, ale podmiot nie oferuje towarów lub usług, określona działalność nie stanowi działalności gospodarczej. Wystąpienie działalności gospodarczej wiąże się dopiero z faktem wejścia na rynek, czyli oferowania towarów i usług, które powinno mieć charakter dobrowolny, a nie obowiązkowy. Przy prowadzeniu działalności gospodarczej nie ma znaczenia status własnościowy podmiotu, bowiem może on stanowić tak własność prywatną, jak i publiczną ${ }^{13}$. Mogą to

8 ETS w sprawach: C-41/90 Klaus Höfner i Fritz Elser przeciwko Macrotron GmbH, ECR 1991, s. I-1979, pkt 21; połączonych C-159/91 oraz C-160/91 Christian Poucet przeciwko Assurances générales de France i Caisse mutuelle régionale du Languedoc-Roussillon, ECR 1993, s. I-637, pkt 17; C-218/00 Cisal di Battistello Venanzio \& C. Sas przeciwko Istituto nazionale per l'assicurazione contro gli infortuni sul lavoro (INAIL), ECR 2002, s. I-691, pkt 22; C-222/04 Ministero dell'Economia e delle Finanze przeciwko Cassa di Risparmio di Firenze SpA, Fondazione Cassa di Risparmio di San Miniato i Cassa di Risparmio di San Miniato SpA, ECR 2006, s. I-289, pkt 107; C-237/04 Enirisorse SpA przeciwko Sotacarbo SpA, ECR 2006, s. I-2843, pkt 28.

9 ETS w sprawach: C-35/96 Komisja Wspólnot Europejskich przeciwko Republice Włoskiej, ECR 1998, s. I-3851, pkt 36; połączonych C-180/98 do C-184/98 Pavel Pavlov i in. przeciwko Stichting Pensioenfonds Medisch Specialisten, ECR 2000, s. I-6451, pkt 75; C-222/04 Ministero dell'Economia e delle Finanze przeciwko Cassa di Risparmio di Firenze SpA, Fondazione Cassa di Risparmio di San Miniato i Cassa di Risparmio di San Miniato SpA, ECR 2006, s. I-289, pkt 108; C-237/04 Enirisorse SpA przeciwko Sotacarbo SpA, ECR 2006, s. I-2843, pkt 29.

${ }^{10}$ ETS w sprawie 323/82 SA Intermills przeciwko Komisji Wspólnot Europejskich, ECR 1984, s. 3809, pkt 11-12.

11 SPI w sprawie T-137/02 Pollmeier Malchow GmbH \& Co. KG przeciwko Komisji Wspólnot Europejskich, ECR 2004, s. II-3541, pkt 50-51.

12 J.L. Buendia Sierra, Exclusive..., s. 32.

13 Definicyjne przesłanki pojęcia przedsiębiorstwa w ujęciu prawa konkurencji Unii Europejskiej musi także spełniać ,,przedsiębiorstwo publiczne” w rozumieniu Dyrektywy Komisji 2006/111/WE z dnia 16 listopada 2006 r. w sprawie przejrzystości stosunków finansowych między państwami członkowskimi a przedsiębiorstwami publicznymi, a także w sprawie przejrzystości 
być zarówno osoby prawne, jak i osoby fizyczne, a także jednostki organizacyjne nieposiadające osobowości prawnej ${ }^{14}$. Podejście to determinuje uznawanie za przedsiębiorstwa z perspektywy reguł pomocy publicznej takie podmioty prowadzące działalność gospodarczą, jak spółki (osobowe i kapitałowe), przedsiębiorstwa państwowe oraz podmioty, dla których organem założycielskim jest gmina lub inna jednostka samorządu terytorialnego ${ }^{15}$. Za przedsiębiorstwa mogą zostać uznane same jednostki samorządu terytorialnego - w przypadku, gdy prowadzą one działalność gospodarczą ${ }^{16}$, a także spółdzielnie ${ }^{17}$, stowarzyszenia ${ }^{18}$ i fundacje $^{19}$. Brak celów dochodowych w prowadzonej przez dany podmiot działalności nie wyklucza uznania tego podmiotu za przedsiębiorstwo ${ }^{20}$. W ujęciu unijnego prawa konkurencji działalnością gospodarczą są nie tylko te czynności, które mają doprowadzić do osiągnięcia zysku ${ }^{21}$. Dlatego też reguły pomocy państwa

finansowej wewnątrz określonych przedsiębiorstw (Dz. Urz. UE L 318/17 z 17.11.2006), niezależnie od tego, czy przedsiębiorstwo to jest beneficjentem pomocy, czy też podmiotem, który udziela pomoc publiczną.

${ }_{14}$ P. Nicolaides, M. Kleis, The Concept of Undertaking in Education and Public Health Systems, „European State Aid Law Quarterly” 2006, no. 3, s. 505.

15 ETS w sprawie 30/87 Corinne Bodson przeciwko SA Pompes funèbres des régions libérées, ECR 1988, s. 2479; SPI w sprawie T-196/04 Ryanair Ltd przeciwko Komisji Wspólnot Europejskich, ECR 2008, s. II-3643, pkt 84-98.

16 W decyzji z dnia 12 grudnia 2008 r. w sprawie N 261/2008 dotyczącej pomocy na promocję odnawialnych źródeł energii w Hiszpanii, Komisja zajęła stanowisko, że dotacja dla gmin wiejskich na zakup paneli słonecznych i instalacji geotermalnych w budynkach publicznych stanowi pomoc państwa w rozumieniu art. 107 ust. 1 TFUE, ponieważ gminy w celu zmniejszenia ponoszonych kosztów elektryczności miały najpierw sprzedawać wytworzoną w tych instalacjach energię elektryczną lokalnemu dystrybutorowi energii, a następnie sukcesywnie kupować od niego tę energię w zależności od bieżącego zapotrzebowania na energię w budynkach publicznych. Gminy posiadały zatem w tym przypadku atrybut przedsiębiorstwa i tym samym podlegały pod przepisy prawa pomocy publicznej, gdyż prowadziły działalność gospodarczą w zakresie sprzedaży i nabywania energii elektrycznej.

17 ETS w sprawie 61/80 Coöperatieve Stremsel- en Kleurselfabriek przeciwko Komisji Wspólnot Europejskich, ECR 1981, s. 851.

18 ETS w sprawach: C-244/94 Fédération française des sociétés d'assurance, Société Paternelle-Vie, Union des assurances de Paris-Vie i Caisse d'assurance et de prévoyance mutuelle des agriculteurs przeciwko Ministère de l'Agriculture et de la Pêche, ECR 1995, s. I-4013; C-67/96 Albany International BV przeciwko Stichting Bedrijfspensioenfonds Textielindustrie, ECR 1999, s. I-5751, pkt 71-87.

19 ETS w sprawie C-222/04 Ministero dell'Economia e delle Finanze przeciwko Cassa di Risparmio di Firenze SpA, Fondazione Cassa di Risparmio di San Miniato i Cassa di Risparmio di San Miniato SpA, ECR 2006, s. I-289.

${ }^{20}$ P.J. Slot, J. Rapp, The Swedish Housing System and its Compatibility with European Competition and State Aid Rules, „European State Aid Law Quarterly” 2008, no. 4, s. 684-704.

${ }^{21}$ ETS w sprawach połączonych 209 do 215 oraz 218/78 Heintz van Landewyck SARL i inni przeciwko Komisji Wspólnot Europejskich, ECR 1980, s. 3125, pkt 88. 
dotyczą w równej mierze tak przedstawicieli wolnych zawodów (np. dentystów) ${ }^{22}$, jak i przedsiębiorstw prowadzących działalność typu non-profit, pod warunkiem, że oferują one towary lub usługi na rynku.

W przepisach unijnego prawa konkurencji pojęcie przedsiębiorstwa zawiera dwa elementy, tj. element podmiotowy (jednostka gospodarcza) i element przedmiotowy (prowadzenie działalności gospodarczej). Elementy te składają się na jednolite, podmiotowo-przedmiotowe pojęcie przedsiębiorstwa. Warunkiem koniecznym, określającym pojęcie przedsiębiorstwa w ujęciu prawa konkurencji UE, jest zatem posiadanie zdolności prawnej, która umożliwia dokonywanie czynności rozporządzających i zobowiązujących, bez możliwości których wykonywania nie można prowadzić działalności gospodarczej. Podmiot, który takiej odpowiedzialności nie może ponosić i który tym samym nie ma zdolności samodzielnego działania na rynku, nie może zostać uznany za przedsiębiorstwo w ujęciu unijnego prawa konkurencji ${ }^{23}$. Dlatego też w przypadkach, gdy niezależne pod względem prawnym osoby fizyczne lub prawne stanowią jedną jednostkę gospodarczą, z punktu widzenia stosowania unijnych reguł konkurencji należy je traktować jako jedno przedsiębiorstwo ${ }^{24}$. Ponadto w rozumieniu przepisów o pomocy publicznej, inaczej niż w przypadku reguł konkurencji skierowanych do przedsiębiorstw, każde przedsiębiorstwo należące do grupy kapitałowej jest odrębnym przedsiębiorstwem, czyli podmiotem autonomicznym pod względem prawnym i finansowym ${ }^{25}$. Wynika to stąd, że w przypadku przepisów prawa antymonopolowego (art. 101 i 102 TFUE) pojęcie przedsiębiorstwa jest ściśle związane z rynkową aktywnością danego podmiotu, co implikuje zakaz pewnych rodzajów zachowań na rynku. Natomiast w przypadku przepisów o pomocy

${ }^{22}$ ETS w sprawie C-172/03 Wolfgang Heiser przeciwko Finanzamt Innsbruck, ECR 2005, s. I-1627, pkt 26.

${ }^{23}$ Pojęcie „przedsiębiorstwo” w ujęciu prawa konkurencji Unii Europejskiej w zakresie pomocy państwa nie może być odniesione do wewnętrznych jednostek organizacyjnych określonych podmiotów - np. działające na gruncie polskiej ustawy o finansach publicznych samorządowe zakłady budżetowe, które realizują wybrane zadania gminy. Takie wyodrębnione pod kątem organizacyjnym jednostki nie mogą w rzeczywistości samodzielnie funkcjonować na rynku, gdyż korzystają w obrocie z osobowości prawnej lub co najmniej zdolności prawnej jednostki macierzystej. Funkcjonalny skutek przepisów o pomocy państwa jest zaś zapewniony poprzez przypisanie przymiotu przedsiębiorstwa jednostce macierzystej, która ma zdolność prawną do przyjęcia przysporzenia i ponoszenia odpowiedzialności prawnej.

${ }^{24}$ ETS w sprawie 170/83 Hydrotherm Gerätebau GmbH przeciwko Firma Compact del Dott. Ing. Mario Andreoli \& C. Sas, ECR 1984, s. 2999, pkt 11; SPI w sprawie T-234/95 DSG Dradenauer Stahlgesellschaft mbH przeciwko Komisji Wspólnot Europejskich, ECR 2000, s. II-2603, pkt 124.

${ }^{25}$ ETS w sprawie C-39/94 Syndicat français de l'Express international (SFEI) $i$ inni przeciwko La Poste oraz inne, ECR 1996, s. I-3547. 
państwa (art. 107-109 TFUE) przedsiębiorstwo nie jest określane przez swoje zachowania na rynku, ale przez okoliczność faktyczną, że jest ono beneficjentem pomocy publicznej. Funkcją traktatowych przepisów o pomocy państwa jest przede wszystkim zdefiniowanie i zidentyfikowanie odbiorcy pomocy.

\section{Interpretacja pojęcia przedsiębiorstwa z perspektywy UOIG}

Trybunał Sprawiedliwości niezmiennie definiuje przedsiębiorstwa jako podmioty prowadzące działalność gospodarczą, niezależnie od ich statusu prawnego i sposobu ich finansowania ${ }^{26}$. Oznacza to, że zakwalifikowanie określonej jednostki jako przedsiębiorstwa zależy całkowicie od charakteru jej działalności. Ta ogólna zasada ma trzy ważne konsekwencje. Po pierwsze, nie jest decydujący status podmiotu na podstawie prawa krajowego. Na przykład podmiot zaklasyfikowany zgodnie z prawem krajowym jako stowarzyszenie lub klub sportowy może jednak zostać uznany za przedsiębiorstwo w rozumieniu art. 107 ust. 1 Traktatu. Jedynym istotnym pod tym względem kryterium jest fakt, czy podmiot ten prowadzi działalność gospodarczą. Po drugie, o stosowaniu reguł pomocy państwa nie decyduje to, czy dany podmiot utworzono po to, aby przynosił zyski. Z orzecznictwa Trybunału Sprawiedliwości i Sądu wynika, że podmioty nienastawione na zysk mogą także oferować na rynku towary i usługi ${ }^{27}$. Jeżeli tak nie jest, to podmioty nienastawione na zysk pozostają oczywiście całkowicie poza zakresem kontroli pomocy państwa. Po trzecie, klasyfikacja podmiotu jako przedsiębiorstwa zawsze odnosi się do konkretnej działalności. Podmiot, który prowadzi zarówno działalność gospodarczą, jak i niegospodarczą, uznaje się za przedsiębiorstwo jedynie w odniesieniu do działalności gospodarczej, przy czym działalnością gospodarczą jest „oferowanie towarów lub usług na danym rynku" ${ }^{28}$. Kwestia tego, czy istnieje rynek dla określonych usług, może zależeć od sposobu organizacji tych usług w danym państwie członkowskim ${ }^{29}$. Reguły pomocy państwa mają zastosowanie jedynie w przypadku, gdy określona

${ }^{26}$ ETS w sprawach połączonych od C-180/98 do C-184/98 Pavel Pavlov i in. przeciwko Stichting Pensioenfonds Medisch Specialisten, ECR 2000, s. I-6451.

27 ETS w sprawach: połączonych od 209/78 do 215/78 oraz 218/78 Van Landewyck, ECR 1980, s. 3125, pkt 21; C-244/94 FFSA i inni, ECR 1995, s. I-4013; C-49/07 MOTOE, ECR 2008, s. I-4863, pkt 27 i 28.

${ }^{28}$ ETS w sprawach: 118/85 Komisja Wspólnot Europejskich przeciwko Republice Włoskiej, ECR 1987, s. 2599, pkt 7; C-35/96 Komisja Wspólnot Europejskich przeciwko Republice Włoskiej, ECR 1998, s. I-3851, pkt 36; C-237/04 Enirisorse SpA przeciwko Sotacarbo SpA, ECR 2006, s. I-2843, pkt 29.

29 ETS w sprawach połączonych C-159/91 i C-160/91 Poucet and Pistre, ECR 1993, s. I-637. 
usługa jest świadczona w otoczeniu rynkowym. Gospodarczy charakter niektórych usług może zatem być różny w poszczególnych państwach członkowskich. Ponadto w związku z wyborami politycznymi lub rozwojem sytuacji gospodarczej klasyfikacja określonej usługi może się zmieniać wraz z upływem czasu. To, co dzisiaj nie stanowi działalności na rynku, może się nią stać w przyszłości i odwrotnie.

Z orzecznictwa Trybunału Sprawiedliwości wynika, że art. 107 Traktatu nie ma zastosowania, jeśli państwo działa „sprawując władzę publiczną"30 lub jeśli organy reprezentujące państwo działają ,w charakterze organów publicznych"31. Można uznać, że dany podmiot działa sprawując władzę publiczną, jeśli przedmiotowa działalność jest zadaniem, które stanowi część zasadniczych funkcji państwa lub jeśli jest ona powiązana z tymi funkcjami poprzez swój charakter, swoje cele i zasady, którym podlega ${ }^{32}$. Zasadniczo działalność, która nieodłącznie stanowi część prerogatyw organu publicznego i jest wykonywana przez państwo, nie stanowi działalności gospodarczej, chyba że dane państwo członkowskie zdecydowało się na wprowadzenie mechanizmów rynkowych. Przykładem takiej działalności jest działalność dotycząca: wojska lub policji; bezpieczeństwa i kontroli żeglugi powietrznej ${ }^{33}$; kontroli i bezpieczeństwa ruchu morskiego ${ }^{34}$; nadzoru nad zanieczyszczeniami ${ }^{35}$ oraz organizacji, finansowania i wykonywania wyroków więzienia ${ }^{36}$.

Od interpretacji pojęcia pomocy publicznej w ujęciu prawa konkurencji UE zależy zakres stosowania art. 107 ust. 1 Traktatu, w szczególności w kontekście obowiązku jej zgłoszenia Komisji, który został ustanowiony w art. 108 ust. 3 TFUE. Analizując konstrukcję zapisu traktatowego, należy stwierdzić, że na pojęcie pomocy publicznej składają się cztery elementy. Są to przesłanki pkt 7 i 8 .

${ }^{30}$ ETS w sprawie C-118/85 Komisja przeciwko Republice Włoskiej, ECR 1987, s. 2599,

${ }^{31}$ ETS w sprawie C-30/87 Bodson/Pompes funèbres des régions libérées, ECR 1988, s. I-2479, pkt 18.

32 ETS w sprawie C-364/92 SAT/Eurocontrol, ECR 1994, s. I-43, pkt 30.

33 ETS w sprawach: C-364/92 SAT/Eurocontrol, ECR 1994, s. I-43, pkt 27; C-113/07 P Selex Sistemi Integrati przeciwko Komisji, ECR 2009, s. I-2207, pkt 71.

${ }_{34}$ Decyzja Komisji z dnia 16 października 2002 r. w sprawie N 438/02 - Belgia - Pomoc dla władz portowych, Dz. Urz. C 284 z 21.11.2002.

${ }_{35}$ ETS w sprawie C-343/95 Calě \& Figli, ECR 1997, s. I-1547, pkt 22.

36 Decyzja Komisji w sprawie N 140/06 - Litwa - Przydział dotacji dla przedsiębiorstw państwowych w zakładach karnych, Dz. Urz. C 244 z 11.10.2006. 
kumulatywne, co oznacza, że niespełnienie choć jednej z nich powoduje brak podstaw do uznania danej interwencji państwa za pomoc publiczną ${ }^{37}$. Pomoc publiczna musi:

- być udzielana przez państwo ${ }^{38}$ lub ze źródeł państwowych ${ }^{39}$,

- uprzywilejowywać niektóre przedsiębiorstwa lub gałęzie produkcji ${ }^{40}$,

- przynosić w jakiejkolwiek formie korzyści ekonomiczne przedsiębior$\mathrm{stwu}^{41}$

- wywierać rzeczywisty lub potencjalny wpływ na konkurencję i wymianę handlową pomiędzy państwami członkowskimi Unii Europejskiej ${ }^{42}$.

Wskazane powyżej przesłanki nie zostały zdefiniowane zarówno w Traktacie, jak i przepisach wtórnego prawa pomocy publicznej ${ }^{43}$. Natomiast wszystkie one były przedmiotem wielu interpretacji, które były dokonywane w ramach stosowania art. 107 i art. 106 ust. 2 TFUE przez Komisję Europejską i sądy Unii Europejskiej. Interpretując te przesłanki w odniesieniu do UOIG wskazać należy, że jedynie korzyści przyznane bezpośrednio lub pośrednio z zasobów państwowych mogą stanowić pomoc państwa w rozumieniu art. 107 Traktatu ${ }^{44}$. Korzyści finansowane z zasobów prywatnych mogą mieć skutek w postaci umocnienia pozycji niektórych przedsiębiorstw, lecz nie wchodzą w zakres art. 107 Traktatu.

37 ETS w sprawie C-222/07 Unión de Televisiones Comerciales Asociadas (UTECA) przeciwko Administración General del Estado, ECR 2009, s. I-1407, pkt 42; SPI w sprawie T-154/10 Republika Francuska przeciwko Komisji Europejskiej, ECR 2012, s. II-nyr, pkt 52.

38 ETS w sprawie C-482/99 Republika Francuska przeciwko Komisji Wspólnot Europejskich (Stardust Marine), ECR 2002, s. I-4397, pkt 51; SPI w sprawie T-351/02 Deutsche Bahn AG przeciwko Komisji Wspólnot Europejskich, ECR 2006, s. II-1047, pkt 101.

39 ETS w sprawach: 82/77 Openbaar Ministerie van het Koninkrijk der Nederlanden przeciwko Jacobus Philippus van Tiggele, ECR 1978, s. 25, pkt 24-25; C-189/91 Petra KirsammerHack przeciwko Nurhan Sidal, ECR 1993, s. I-6185, pkt 16.

${ }^{40}$ ETS w sprawach: C-200/97 Ecotrade Srl przeciwko Altiforni e Ferriere di Servola SpA (AFS), ECR 1998, s. I-7907, pkt 40; C-143/99 Adria-Wien Pipeline GmbH i Wietersdorfer \& Peggauer Zementwerke GmbH przeciwko Finanzlandesdirektion für Kärnten, ECR 2001, s. I-8365, pkt 41.

${ }^{41}$ ETS w sprawie C-342/96 Królestwo Hiszpanii przeciwko Komisji Wspólnot Europejskich (Tubacex), ECR 1999, s. I-2459, pkt 41; SPI w sprawie T-196/04 Ryanair Ltd przeciwko Komisji Wspólnot Europejskich, ECR 2008, s. II-3643, pkt 39.

${ }^{42}$ ETS w sprawach: C-372/97 Republika Włoska przeciwko Komisji Wspólnot Europejskich, ECR 2004, s. I-3679, pkt 44; C-148/04 Unicredito Italiano SpA przeciwko Agenzia delle Entrate, Ufficio Genova 1, ECR 2005, s. I-11137, pkt 55.

${ }^{43}$ C. Quigley, The notion of the State aid in the EEC, „European Law Review” 1998, no. 13, s. 242; J. Winter, Re(de)fining the notion of State aid in Article 87(1) of the EC Treaty, „Common Market Law Review” 2004, no. 41, s. 475.

${ }^{44}$ ETS w sprawach: połączonych od C-52/97 do C-54/97 Viscido $i$ in., ECR 1998, s. I-2629, pkt 13; C-53/00 Ferring, ECR 2001, s. I-9067, pkt 16; C-379/98 PreussenElektra przeciwko Schleswag, ECR 2001, s. I-2099. 
Taki transfer zasobów państwowych może przyjmować wiele form, np. dotacji bezpośrednich, ulg podatkowych i świadczeń w naturze. W szczególności fakt, że państwo nie nalicza cen rynkowych za niektóre usługi, stanowi rezygnację z zasobów państwowych. W wyroku w sprawie C-482/99 Francja przeciwko Komisji ${ }^{45}$ Trybunał Sprawiedliwości potwierdził również, że zasoby przedsiębiorstwa publicznego stanowią zasoby państwowe w rozumieniu art. 107 Traktatu, ponieważ organy publiczne są w stanie kontrolować te zasoby. W przypadkach gdy przedsiębiorstwo, któremu powierzono wykonywanie określonej UOIG, jest finansowane $\mathrm{z}$ zasobów zapewnianych przez przedsiębiorstwo publiczne i finansowanie to można przypisać państwu, finansowanie to może potencjalnie stanowić pomoc państwa. Państwa członkowskie mogą w niektórych przypadkach finansować UOIG z opłat lub składek wnoszonych przez niektóre przedsiębiorstwa lub użytkowników, z których przychód jest przekazywany przedsiębiorstwom, którym powierzono wykonywanie danej UOIG. Tego rodzaju uzgodnienia finansowe były analizowane przez Trybunał Sprawiedliwości, zwłaszcza w wyroku w sprawie 173/73 Włochy przeciwko Komisji46, w którym Trybunał stwierdził, że: „Skoro przedmiotowe fundusze są finansowane poprzez obowiązkowe składki wymagane prawem krajowym, a - jak pokazuje niniejszy przypadek - są zarządzane i przydzielane zgodnie z przepisami tego prawa, należy je uznać za zasoby państwowe w rozumieniu art. 107 Traktatu, nawet jeśli są zarządzane przez instytucje odrębne od organów publicznych". Podobnie w wyroku z dnia 11 marca 1992 r. w sprawach połączonych C-78/90 do C-83/90 Compagnie Commerciale de l'Ouest ${ }^{47}$ Trybunał Sprawiedliwości potwierdził, że środki finansowane z opłat parafiskalnych stanowią środki finansowane z zasobów państwowych. Ponadto płatności z tytułu rekompensaty za wykonywanie UOIG, które są finansowane z opłat parafiskalnych lub obowiązkowych składek nakładanych przez państwo oraz zarządzanych i przydzielanych zgodnie z przepisami wspomnianego prawa, są płatnościami z tytułu rekompensaty dokonywanymi z zasobów państwowych.

Aby rekompensata z tytułu świadczenia usług publicznych podlegała art. 107 Traktatu, musi wywierać wpływ na wymianę handlową między państwami

45 ETS w sprawie C-482/99 Francja przeciwko Komisji, ECR 2002, s. I-4397.

46 ETS w sprawie 173/73 Włochy przeciwko Komisji, ECR 1974, s. 709, pkt 16. Zob. także ETS w sprawach: 78/79 Steinike, ECR 1977, s. 595, pkt 21, C 206/06 Essent Netwerk, ECR 2008, s. 5497, pkt 47, 57 i 96.

47 ETS w sprawach połączonych C-78/90 do C-83/90 Compagnie Commerciale de l'Ouest i in. przeciwko Receveur Principal des Douanes de La Pallice Port, ECR 1992, s. I-1847, pkt 35. Zob. również ETS w sprawach połączonych od C-34/01 do C-38/01 Enirisorse SpA przeciwko Ministero delle Finanze, ECR 2003, s. I-14243, pkt 26. 
członkowskimi lub stwarzać zagrożenie wywarcia takiego wpływu. Taki wpływ zasadniczo zakłada istnienie rynku otwartego na konkurencję. W związku z tym w przypadkach, gdy otwarcie rynków na konkurencję nastąpiło wskutek przepisów unijnych lub krajowych czy faktycznego rozwoju gospodarczego, obowiązują reguły pomocy państwa. W takich sytuacjach państwa członkowskie zachowują swobodę decydowania o tym, w jaki sposób zdefiniować, zorganizować i finansować UOIG podlegające kontroli pomocy państwa, jeżeli podmiotowi świadczącemu UOIG przyznaje się rekompensatę, bez względu na to, czy jest to podmiot publiczny, czy prywatny. Jeżeli rynek jest zastrzeżony dla jednego przedsiębiorstwa, przyznana mu rekompensata podlega również kontroli pomocy państwa. Tak więc jeżeli działalność gospodarczą otwarto na konkurencję, decyzje o zapewnieniu UOIG innymi metodami niż przy zastosowaniu procedury zamówień publicznych, która gwarantuje najniższy koszt dla społeczności, mogą prowadzić do zakłóceń polegających na uniemożliwianiu konkurentom wejścia na rynek lub ułatwianiu beneficjentowi ekspansji na innych rynkach. Zakłócenia mogą także wystąpić na rynkach czynników produkcji. Pomoc przyznana przedsiębiorstwu działającemu na rynku niezliberalizowanym może wywierać wpływ na wymianę handlową, jeśli przedsiębiorstwo-beneficjent działa również na rynkach zliberalizowanych ${ }^{48}$. Środki pomocy mogą wywierać wpływ na wymianę handlową również jeśli samo przedsiębiorstwo-beneficjent nie uczestniczy w działalności transgranicznej. W takich przypadkach podaż krajowa może utrzymać się lub zwiększyć, wskutek czego przedsiębiorstwa mające siedzibę w innych państwach członkowskich mają ograniczone możliwości oferowania swoich usług w tym państwie członkowskim ${ }^{49}$.

Zatem w przypadku, gdy działalność beneficjenta pomocy na UOIG ma charakter gospodarczy i narusza wymianę handlową między państwami członkowskimi, zastosowanie mają reguły konkurencji określone w Traktacie. Należy jednak wskazać, że usługi świadczone w ogólnym interesie gospodarczym mają często zasięg wyłącznie lokalny. Czy rzeczywiście wpływają więc na wymianę handlową między państwami członkowskimi? W przypadku przepisów dotyczących pomocy państwa kwestia wpływu na wymianę handlową nie zależy jednak od tego, czy świadczona usługa ma zasięg lokalny, czy regionalny, ani też od skali danej działalności. Fakt, iż kwota pomocy lub wielkość podmiotu ją

48 SPI w sprawach połączonych T-298/97, T-312/97, T-313/97, T-315/97, T-600/97 do T-607/97, T-1/98, T-3/98 do T-6/98 oraz T-23/98, Mauro Alzetta $i$ inni przeciwko Komisji, ECR 2000, s. II-2319, pkt 143-147.

49 Zob.w szczególnościETS w sprawieC-280/00AltmarkTrans GmbHiRegierungspräsidium Magdeburg przeciwko Nahverkehrsgesellschaft Altmark GmbH, ECR 2003, s. I-7747. 
otrzymującego jest stosunkowo nieduża, nie wyklucza tego, iż może ona wpływać na wymianę handlową między państwami członkowskimi ${ }^{50}$. W rezultacie nawet pomoc w niewielkiej kwocie może zwiększyć ofertę usług jednego dostawcy, utrudniając tym samym innym przedsiębiorcom europejskim możliwość świadczenia tych samych usług na rynku lokalnym. W oparciu o dotychczasowe doświadczenia Komisja Europejska określiła jednak progi, do których pomoc nie ma wpływu na wymianę handlową ani konkurencję. W rozporządzeniu w sprawie pomocy de minimis dotyczącej usług świadczonych w ogólnym interesie gospodarczym $^{51}$ Komisja przyjmuje na przykład, że pomoc na świadczenie tych usług nieprzekraczająca pułapu 500000 EUR w dowolnym okresie trzech lat nie wpływa na handel między państwami członkowskimi i nie zakłóca ani nie grozi zakłóceniem konkurencji, a zatem nie podlega przepisom art. 107 ust. 1 TFUE. Ponadto na podstawie ogólnego rozporządzenia dotyczącego pomocy de mini$m i s^{52}$ uznaje się, że pomoc nieprzekraczająca pułapu 200000 EUR (100 000 EUR w przypadku przedsiębiorstw działających w sektorze transportu drogowego) nie wpływa na wymianę handlową między państwami członkowskimi.

\section{Podsumowanie}

Zasady Traktatu dotyczące pomocy państwa odnoszą się do organizacji i finansowania UOIG w sytuacji, gdy odbiorcą pomocy jest przedsiębiorstwo. Koncepcja ta obejmuje dowolny podmiot zaangażowany w działalność gospodarczą, bez względu na jego status prawny lub sposób finansowania takiego podmiotu - np. przez jednostki samorządu terytorialnego. Działalnością gospodarczą jest natomiast dowolna działalność polegająca na oferowaniu towarów i/lub usług na danym rynku. Jeżeli działalność odbiorcy pomocy na UOIG ma charakter gospodarczy i wpływa na wymianę handlową między państwami członkowskimi, zastosowanie mają reguły konkurencji. Zastosowanie reguł konkurencji nie oznacza, że państwa członkowskie muszą zmienić organizację i funkcjonowanie

50 SPI w sprawie T-214/95 Vlaams Gewest przeciwko Komisji, ECR 1998, s. II-717, pkt 4850; ETS w sprawach: C-280/00 Altmark Trans $i$ Regierungspräsidium Magdeburg, ECR 2003, s. I-7747, pkt 81-82; C-172/03 Heiser, ECR 2005, s. I-1627, pkt 32-33.

51 Rozporządzenie Komisji (UE) nr 360/2012 z dnia 25 kwietnia 2012 r. w sprawie stosowania art. 107 i 108 Traktatu o funkcjonowaniu Unii Europejskiej do pomocy de minimis przyznawanej przedsiębiorstwom wykonującym usługi świadczone w ogólnym interesie gospodarczym, Dz. Urz. UE L 114/8 z 26.04.2012.

52 Rozporządzenie Komisji (UE) nr 1407/2013 z dnia 18 grudnia 2013 r. w sprawie stosowania art. 107 i 108 Traktatu o funkcjonowaniu Unii Europejskiej do pomocy de minimis, Dz. Urz. UE L 352/1 z 24.12.2013. 
swojego systemu usług świadczonych w ogólnym interesie gospodarczym. Fakt zastosowania reguł konkurencji nie oznacza, że jednostki samorządu terytorialnego muszą dopilnować, aby na rynku zawsze działała duża liczba usługodawców. Nie oznacza to również, że jednostki samorządu terytorialnego mają obowiązek zniesienia przyznanych wcześniej usługodawcom specjalnych lub wyłącznych praw, które są niezbędne dla celów danych usług świadczonych w ogólnym interesie gospodarczym i proporcjonalne w odniesieniu do tych celów. Jednostki samorządu terytorialnego mogą przyznawać tego rodzaju prawa, jeżeli tylko nie wykraczają one poza to, co jest niezbędne do zapewnienia wykonania zadań leżących w interesie ogólnym na warunkach dopuszczalnych pod względem gospodarczym.

\section{Literatura}

Bacon K., The definition of State Aid, w: European Community Law of State Aid, red. K. Bacon, Oxford University Press, Oxford-New York 2009.

Buendia Sierra J.L., Exclusive Rights and State Monopolies under EC Law: Article 86 (former Article 90) of the EC Treaty, Oxford University Press, Oxford-New York 2000.

Decyzja Komisji z dnia 16 października 2002 r. w sprawie N 438/02 - Belgia - Pomoc dla władz portowych, Dz. Urz. C 284 z 21.11.2002.

Decyzja Komisji w sprawie N 140/06 - Litwa - Przydział dotacji dla przedsiębiorstw państwowych w zakładach karnych, Dz. Urz. C 244 z 11.10.2006.

Dyrektywa Komisji 2006/111/WE z dnia 16 listopada 2006 r. w sprawie przejrzystości stosunków finansowych między państwami członkowskimi a przedsiębiorstwami publicznymi, a także w sprawie przejrzystości finansowej wewnątrz określonych przedsiębiorstw, Dz. Urz. UE L 318/17 z 17.11.2006.

Nicolaides P., Kleis M., The Concept of Undertaking in Education and Public Health Systems, ,European State Aid Law Quarterly” 2006, no. 3.

Quigley C., The notion of the State aid in the EEC, „European Law Review” 1998, no. 13.

Rozporządzenie Komisji (UE) nr 360/2012 z dnia 25 kwietnia 2012 r. w sprawie stosowania art. 107 i 108 Traktatu o funkcjonowaniu Unii Europejskiej do pomocy de minimis przyznawanej przedsiębiorstwom wykonującym usługi świadczone w ogólnym interesie gospodarczym, Dz. Urz. UE L 114/8 z 26.04.2012.

Rozporządzenie Komisji (UE) nr 1407/2013 z dnia 18 grudnia 2013 r. w sprawie stosowania art. 107 i 108 Traktatu o funkcjonowaniu Unii Europejskiej do pomocy de minimis, Dz. Urz. UE L 352/1 z 24.12.2013.

Slot P.J., Rapp J., The Swedish Housing System and its Compatibility with European Competition and State Aid Rules, „European State Aid Law Quarterly” 2008, no. 4. 
Sudoł S., Przedsiębiorstwo. Podstawy nauki o przedsiębiorstwie. Teorie i praktyka zarzadzania, Dom Organizatora TNOiK, Toruń 2002.

Traktat o Unii Europejskiej i Traktat o funkcjonowaniu Unii Europejskiej, wersje skonsolidowane - Dz. Urz. UE, C 83 z 30.03.2010.

Ustawa z dnia 27 sierpnia 2009 r. o finansach publicznych, DzU z 2009 r. nr 157, poz. 1240 z późn. zm.

Van de Castelle K., M. Hocine, „Favouring certain undertakings or the production of certain goods": Selectivity, w: EU Competition Law, vol. IV: State Aid, red. W. Mederer, N. Pesaresi, M. Van Hoof M., Claeys \& Casteels Publishing BV, Lueven 2008.

Winter J., Re(de)fining the notion of State aid in Article 87(1) of the EC Treaty, „Common Market Law Review" 2004, no. 41.

\title{
THE DEFINITION OF UNDERTAKING \\ AS A BENEFICIARY OF STATE AID GRANTED \\ FOR SERVICES OF GENERAL ECONOMIC INTEREST REALIZED \\ BY LOCAL GOVERNMENT UNITS
}

\begin{abstract}
Summary
The concept of service of general economic interest (SGEI) is an evolving notion that depends, among other things, on the needs of citizens, technological and market developments and social and political preferences in the Member State concerned. It transpires from Article 106(2) of the Treaty that undertakings entrusted with the operation of SGEIs are undertakings entrusted with 'a particular task'. Generally speaking, the entrustment of a 'particular public service task' implies the supply of services which, if it were considering its own commercial interest, an undertaking would not assume or would not assume to the same extent or under the same conditions. Based on Article 107(1) of the Treaty, the State aid rules generally only apply where the recipient is an 'undertaking'. Whether or not the provider of a service of general interest is to be regarded as an undertaking is therefore fundamental for the application of the State aid rules.
\end{abstract}

Keywords: State aid, the European Union, local government units, undertaking, services of general economic interest 
